\title{
APC I1307K and the E1317Q variants are not present in Chinese colorectal cancer patients
}

\author{
Jiayi Guo, $M S c^{1}$, Robert Lim, $M D^{1}$, Ross Soo, $M D^{1}$, Adrian Leong, $M D^{2}$, and Soo Chin Lee, $M D^{1}$
}

\begin{abstract}
Purpose: The APC I1307K and E1317Q variants predispose to colorectal adenomas and carcinomas in Caucasians, but data are lacking in Asians. Methods and Results: We sequenced the APC gene from codons 1261 to 1409 and found none of 147 Chinese, 20 Malay, and 11 Indian colorectal cancer patients in Singapore to carry the APC I1307K or E1317Q variants. Conclusion: These variants are rare in these Asian populations, and play little role in colorectal cancer causation in Chinese. Genet Med 2004:6(4):237-238.
\end{abstract}

Key Words: APC I1307K, APC E1317Q, Asian, Chinese, colorectal cancer

The APC gene is important in the pathogenesis of both hereditary and sporadic colorectal cancer. Germline mutations are associated with familial adenomatous polyposis, and inactivating somatic mutations between codons 168 and 1680 are important in sporadic colorectal carcinogenesis. ${ }^{1}$ Low penetrant germline $A P C$ variants, including the $I 1307 \mathrm{~K}$ and $E 1317 \mathrm{Q}$ variants, predispose to colorectal adenomas and carcinoma. ${ }^{2-6}$ The APC I1307K variant creates a hypermutable poly-A tract (A8) that increases the chances of adjacent truncating somatic mutations. ${ }^{2}$ The resultant amino acid change may also have a direct functional effect due to a charge change. ${ }^{7}$ This variant has been reported exclusively in the Ashkenazi ${ }^{2,7,8}$ and Yemenite Jewish populations. ${ }^{9}$ Like the $I 1307 \mathrm{~K}$ variant, the E1317Q variant results in a charge difference from a single amino acid change. ${ }^{6}$ As opposed to the $I 1307 \mathrm{~K}$ variant, this variant is present in both Ashkenazi Jewish and non-Ashkenazi Jewish Caucasian populations, and is believed to predispose to colonic adenomas and carcinomas. ${ }^{5,6}$ It is rare in the general Caucasian population, but is found in $1 \%$ to $4 \%$ of patients with colorectal cancer or adenomas. ${ }^{5,6}$

Genetic testing for the APC I1307K and E1317Q variants may identify individuals at high risk for colorectal cancer who may benefit from surveillance or preventive strategies. ${ }^{4}$ With exception of limited data of the APC $11307 \mathrm{~K}$ variant in Hawaiian Japanese, ${ }^{8}$ the influence of neither variant on colorectal adenoma and carcinoma pathogenesis in Asians is unknown.

\section{MATERIALS AND METHODS}

We recruited any colorectal cancer patients who were of Chinese, Malay, or Indian origin, from the National University

\footnotetext{
From the ${ }^{1}$ Departments of Haematology-Oncology and ${ }^{2}$ Surgery, National University Hospital, Singapore.

Soo Chin Lee, MD, Department of Haematology-Oncology, National University Hospital, Singapore, 5, Lower Kent Ridge Road, Singapore 119074, Singapore.

Received: March 31, 2004

Accepted: April 29, 2004.
}

DOI: 10.1097/01.GIM.0000132687.93304.C6
Hospital Cancer Centre, Singapore. Participants provided written informed consent, a three-generation family cancer history, and germline DNA from peripheral blood, and were given the option to be informed of a positive result with genetic counseling as appropriate. Genomic DNA was isolated using the Puregene DNA Isolation kit (Gentra Systems, Inc., Minneapolis, MN). A 449-bp segment of the APC gene encompassing the $11307 \mathrm{~K}$ and $E 1317 \mathrm{Q}$ variants, from codons 1261 to 1409 was amplified from $300 \mathrm{ng}$ genomic DNA with polymerase chain reaction (PCR). Three DNA samples with the APC I1307K mutation, kindly provided by Dr J.R. Eshleman (Johns Hopkins School of Medicine, Baltimore, MD), served as positive controls. PCR were performed in $50 \mu \mathrm{L}$ volumes containing $1 \times$ PCR buffer $\left(10 \mathrm{mmol} / \mathrm{L}\right.$ Tris- $\mathrm{HCl}, \mathrm{pH} 9.0$ at $25^{\circ} \mathrm{C}, 50$ $\mathrm{mmol} / \mathrm{L} \mathrm{KCl}, 0.1 \%$ Triton X-100), $0.2 \mathrm{mmol} / \mathrm{L}$ each of dNTPs, 1.5U Taq DNA polymerase (Qiagen Inc., Valencia, CA), 2 $\mathrm{mmol} / \mathrm{L} \mathrm{MgCl}_{2}, 1 \times \mathrm{Q}$-Solution (Qiagen), and $0.25 \mu \mathrm{mol} / \mathrm{L}$ each of forward (5'-GACTTATTGTGTAGAAGATAC) and reverse primer (5'-ATGGTTCACTCTGAACGGA). PCR conditions were an initial denaturation at $95^{\circ} \mathrm{C}$ for 2 minutes, followed by 38 cycles of amplification $\left(95^{\circ} \mathrm{C}\right.$ for 30 seconds, $51^{\circ} \mathrm{C}$ for 2 minutes, and $72^{\circ} \mathrm{C}$ for 2 minutes), and a final extension step at $72^{\circ} \mathrm{C}$ for 7 minutes. PCR products were visualized by electrophoresis on $1 \%$ agarose gel, and purified using the QIAquick PCR purification kit (Qiagen Inc.). Purified PCR products were sequenced with the PCR forward primer using the BigDye Terminator v3.0 kit (Perkin-Elmer Applied Biosystems, Foster City, CA). Sequencing products were run on the ABI PRISM 3100 Genetic Analyzer (Perkin-Elmer Applied Biosystems), analyzed using the Sequencing Analysis 3.0 software (Perkin-Elmer Applied Biosystems), and compared with the reference sequence (Genbank NM000038).

\section{RESULTS}

A total of 178 patients participated. The majority was Chinese, $22 \%$ had history of adenomatous polyps, and none had classic familial adenomatous polyposis (Table 1). Thirty-three patients were suspected clinically to have HNPCC because they 
Guo et al.

Table 1

Demographic and clinical characteristics of patients $(n=178)$

\begin{tabular}{|c|c|}
\hline Characteristic & No. (Percentage) \\
\hline \multicolumn{2}{|l|}{ Ethnic group } \\
\hline Chinese & $147(83 \%)$ \\
\hline Malay & $20(11 \%)$ \\
\hline Indian & $11(6 \%)$ \\
\hline \multicolumn{2}{|l|}{ Gender } \\
\hline Male & $106(60 \%)$ \\
\hline Female & $72(40 \%)$ \\
\hline \multicolumn{2}{|l|}{ Age } \\
\hline Median & 54 \\
\hline Range & $19-85$ \\
\hline \multicolumn{2}{|l|}{ Family history } \\
\hline No family history of colorectal cancer & $138(78 \%)$ \\
\hline $\begin{array}{l}\text { At least one first- or second-degree relative with } \\
\text { colorectal cancer }\end{array}$ & $40(22 \%)$ \\
\hline Suspected HNPCC & $33(19 \%)$ \\
\hline \multicolumn{2}{|l|}{ Personal history of adenomatous polyps } \\
\hline None & $139(78 \%)$ \\
\hline One or more & $39(22 \%)$ \\
\hline \multicolumn{2}{|l|}{$\begin{array}{l}\text { Number of adenomatous polyps among patients with at } \\
\text { least one polyp }(\mathrm{n}=39)\end{array}$} \\
\hline Median & 2 \\
\hline Range & $1-21$ \\
\hline
\end{tabular}

fulfilled the Amsterdam $\mathrm{I} / \mathrm{II}^{10}$ or Bethesda criteria. ${ }^{11}$ None of the patients carried a germline mutation in the $A P C$ gene from codons 1261 to 1409 , including specifically the APC I1307K and $E 1317 Q$ variants.

\section{DISCUSSION}

This study represents the first among non-Jewish populations within Asia. Our findings further confirmed the APC $I 1307 \mathrm{~K}$ variant to be unique to the Jewish population. Given our large cohort of Chinese patients, we were able to conclude that the APC $11307 \mathrm{~K}$ and the $E 1317 \mathrm{Q}$ variants are either absent, or present at $<1 \%$ prevalence in Singaporean Chinese colorectal cancer patients, and that they play little to no role in the causation of colorectal cancer in Singaporean Chinese. As Singaporean Chinese originate from Southern China, these findings may be extrapolated to the Chinese in mainland China. Although we did not identify these variants in Malays and Indians, we were unable to conclusively exclude their presence in these ethnic populations given our small sample size. The significance of these variants in Malays and Indians can only be ascertained by expanding the study to a larger cohort.

\section{ACKNOWLEDGMENTS}

This study is supported by the NUH Molecular Diagnosis Centre grant (EF/2001/07/ROC-007). We thank all participants, May-Chin Yong, A/Prof James R. Eshleman, Johns Hopkins University, and A/Prof Evelyn Koay, Molecular Diagnostics Laboratory, NUH for technical assistance.

\section{References}

1. Miyoshi Y, Nagase H, Ando H, Horii A, Ichii S, Nakatsuru S et al. Somatic mutations of the APC gene in colorectal tumors: mutation cluster region in the APC gene. Hum Mol Genet 1992;1:229-233.

2. Laken SJ, Petersen GM, Gruber SB, Oddoux C, Ostrer H, Giardiello FM et al. Familial colorectal cancer in Ashkenazim due to a hypermutable tract in APC. Nat Genet 1997; 17:79-83.

3. Stern HS, Viertelhausen S, Hunter AG, O'Rourke K, Cappelli M, Perras H, Serfas K et al. APC I1307K increases risk of transition from polyp to colorectal carcinoma in Ashkenazi Jews. Gastroenterology 2001;120:392-400.

4. Rozen P, Naiman T, Strul H, Taussky P, Karminsky N, Shomrat R et al. Clinical and screening implications of the $11307 \mathrm{~K}$ adenomatous polyposis coli gene variant in Israeli Ashkenazi Jews with familial colorectal neoplasia. Evidence for a founder effect. Cancer 2002;94:2561-2568.

5. Lamlum H, Al Tassan N, Jaeger E, Frayling I, Sieber O, Reza FB et al. Germline APC variants in patients with multiple colorectal adenomas, with evidence for the particular importance of E1317Q. Hum Mol Genet 2000;9:2215-2221.

6. Frayling IM, Beck NE, Ilyas M, Dove-Edwin I, Goodman P, Pack K et al. The APC variants $\mathrm{I} 1307 \mathrm{~K}$ and $\mathrm{E} 1317 \mathrm{Q}$ are associated with colorectal tumors, but not always with a family history. Proc Natl Acad Sci U S A 1998;95:10722-10727.

7. Evertsson S, Lindblom A, Sun XF. APC I1307K and E1317Q variants are rare or do not occur in Swedish colorectal cancer patients. Eur J Cancer 2001;37:499-502.

8. Prior TW, Chadwick RB, Papp AC, Arcot AN, Isa AM, Pearl DK et al. The I1307K polymorphism of the APC gene in colorectal cancer. Gastroenterology 1999;116:5863.

9. Drucker L, Shpilberg O, Neumann A, Shapira J, Stackievicz R, Beyth Y et al. Adenomatous polyposis coli I1307K mutation in Jewish patients with different ethnicity: prevalence and phenotype. Cancer 2000;88:755-760.

10. Vasen HF, Watson P, Mecklin JP, Lynch HT. New clinical criteria for hereditary nonpolyposis colorectal cancer (HNPCC, Lynch syndrome) proposed by the International Collaborative group on HNPCC. Gastroenterology 1999;116:1453-1456.

11. Umar A, Boland CR, Terdiman JP, Syngal S, de la Chapelle A, Ruschoff J et al Revised Bethesda Guidelines for hereditary nonpolyposis colorectal cancer (Lynch syndrome) and microsatellite instability. J Natl Cancer Inst 2004;96:261-268. 